\title{
САМОТОЖДЕСТВО Я ВО ВНУТРЕННЕМ ДИАЛОГЕ
}

\section{Е.Б. СТАРОВОЙТЕНКО}

${ }^{a}$ Национальньй исследовательский университет «Высшая школа экономики», 101000, Россия, Москва, ул. Мясницкая, д. 20

\section{Резюме}

Исследование, представленное в данной статье, основывается на определении науки в качестве области культуры, предложенном Т. Куном. С этих позиций психология личности, общая персонология выступают открытым миром культурных феноменов, представляющих собой хорошо работающие идеи и теории, модели и научные факты, методы и практики, интерпретации и коммуникации. Потенциал и генез данных феноменов может раскрываться «культурной феноменологией личности». Используя метод герменевтики, метод моделирования и метод построения рефлексивных практик, релевантные культурной феноменологии личности, автор выдвигает идею о внутреннем диалоге Я - Другой как существенном внутриличностном условии развития самотождества Я. В понимании самотождества акцентируется его «достижение» как путь, на котором тенденция Я к сохранению «себя» встречает вызовы Я к разотождествлению с собой и самоотождествлению на новых уровнях. Предлагается структура развивающего диалога, ориентированного на многомерное рефлексивное раскрытие Я в отношении к Другому с позиций «Я-сам» и с позиций «внутреннего Другого». Обосновывается, что такой диалог может обогащать и усиливать самотождество Я через гармонизацию, проблематизацию и синтез Я-репрезентаций, полученных с указанных позиций. Авторская идея нашла разработку в виде континуума «герменевтическая модель - теоретическая модель - рефлексивная модель», который служит изучению и актуализации возможностей достижения самотождества Я во внутреннем диалоге.

Ключевые слова: персонология, культурная феноменология, герменевтика, модель, личность, Я, Другой, внутренний диалог, самотождество Я, достижение самотождества, разотождествление с собой, рефлексия.

\section{Исследование личности с позиций культурной феноменологии}

Основой данного исследования выступает определение науки в качестве плодотворной области культуры (Кун, 2002). Культура понимается как мир воссоздания продуктивных жизненных состояний человека: познания и творчества, рефлексии и практической деятельности, порождения смыслов и ценностей, диалогов и текстов. Наука, научно-исследовательская деятельность, актуализирует все эти состояния с преобладанием познавательных, творческих, практических. 
Наука в культурном контексте - «исследования, прочно опирающиеся на прошлые достижения, которые в течение некоторого времени признаются определенным научным сообществом как основа для его дальнейшей практической деятельности» (Там же, с. 34). Фундаментальные научные достижения представлены в произведениях, освещающих теории, в которых многие поколения ученых находят для себя разнообразные научные проблемы, связанные с различными типами применения теорий: концептуальным, инструментальным и эмпирическим. Уникальность авторства, аудитории, особые ценности научной группы, активная вовлеченность в нее круга лиц, творящих науку и использующих ее плоды, - специфические характеристики науки, которая «развивается не таким образом, как любая другая область культуры» (там же, c. 268).

Наука - открытый мир культурных феноменов, представляющих собой хорошо работающие идеи, теории, модели, научные факты, методы и практики, интерпретации и коммуникации, а также личности и Я их создателей и многочисленных последователей. Ресурс, потенциал и генез данных феноменов может раскрываться «культурной феноменологией» с ее референциями и отличиями от феноменологии культуры (Гуссерль, 1999; Шпет, 1996; Мотрошилова, 1968; Туровский, 1997).

С этой точки зрения, психология личности, особенно в формате общей персонологии (Петровский, Старовойтенко, 2012), может рассматриваться в качестве культурной феноменологии личности, задачами которой являются развитие идей на основе творческих интерпретаций текстов произведений о личности, создание новых концепций и моделей личности, обогащение культурных «фактов личности», построение психопрактик и методов эмпирических исследований, конституированных моделями и «фактами личности».

В области культурной феноменологии личности произведение становится для исследователя «духовным инструментом», посредством которого он дает пробудиться в себе тому, о чем говорит автор, - «совершить собственный внутренний акт». Это не собрание великих изречений, а средство узнавания или порождения в себе эквивалентов состояний переживания, познания и творчества автора (Мамардашвили, 1997). Они воссоздаются в процессе применения герменевтического подхода (Гадамер, 1988; Рикер, 1995), состоящего в обращении исследователя к изучаемым феноменам, в его понимании и интерпретации текста как важной части культурного опыта, в диалоге с автором, в рефлексии исследователя, в постижении идеи текста, выработке новых идей и представлений, в преодолении традиций, в продуктивности и извлечении смыслов, направляющих дальнейшее понимание и творчество исследователей, в обретении «состояния новой духовной свободы». В отношении «текстов личности», релевантных для общей персонологии, мы, следуя идеям В. Дильтея, М. Хайдеггера, Ж.-П. Сартра, П. Рикера, М.К. Мамардашвили, наметили еще ряд аспектов герменевтического подхода (Старовойтенко, 2015). Это работа с «текстом личности», относящимся к категории философских, психологических, художественных, рефлексивных текстов; интерпретация текста, построенная как исследование определенной проблемы личности; 
разработка и применение инструментальной модели, задающей процедуру интерпретации как научного творчества; использование разнообразных герменевтических действий с текстом; выявление неизвестных ранее содержаний текста, относящихся к проблеме исследования; изучение опыта автора как «практикующего феноменолога», т.е. человека, способного открыть и описать ключевые феномены жизни личности; определение места изучаемого текста в континууме других текстовых репрезентаций «личности» и изучаемой проблемы; интерсубъектная позиция исследователя, предполагающая диалоги с другими интерпретаторами произведения; диалог с собой как «досоздателем» текста; соотнесение исследователем своего понимания текста с другими интерпретациями, обнаружение их общности, противоречий и возможностей синтеза; определение места осуществленного герменевтического поиска в познании личности; разработка исследователем на основе результатов герменевтики концептуального подхода к решению проблемы.

Извлечение из содержания произведений теоретических положений, фактов и кейсов «личности» как культурных феноменов может стать материалом для создания герменевтической модели ранее достигнутого знания о предмете, проблематизированного исследователем. На ее основе может быть создана новая модель предмета и способа его изучения, предлагающая авторское решение проблемы в виде концепции, метода, практики или их континуума.

Наша работа посвящена изложению результатов персонологического исследования самотождества Я во внутреннем диалоге со значимым Другим. Оно явилось продолжением исследований автора, посвященных возможностям и генезу Я в отношении Я - Другой и приобретению этим отношением диалогичного или недиалогичного характера (Старовойтенко, 2013, 2016, 2017; Starovoytenko, 2018b). В ходе изучения Я в контексте диалога с Другим, на основе его результатов, а также при обращении к выдающимся опытам экзистенциального и феноменологического раскрытия самотождественности личности, встал вопрос об условиях сохранения и развития самотождества Я, в частности о роли внутреннего диалога. Авторским ответом на этот вопрос стала данная статья.

Самотождество Я, являясь одной из фундаментальных и наиболее сложных психологических проблем, исследуется в основном в парадигме «идентичности» как обретения тождества Я с «другим» - культурой, социумом, группой, конкретными людьми; в меньшей степени раскрывается «самоидентичность» как способность Я совпадать с собой, быть собой, признавать себя собой, быть тождественным себе (Андреева, 2009; Белинская, 2018; Леонтьев, 2009; Рассказова, Тхостов, 2012; Зарецкий, 2007; Эриксон, 1996; Gallagher, 1992; Jaromowic, 1998). В области проблем, ожидающих решения, остаются закономерности динамики, взаимопереходов идентичности и самоидентичности личности, а также те жизненные и личностные условия, которые не просто способствуют устойчивости идентификации Я с собой, а конституируют «достижение самотождества», или «достижение себя» (Старовойтенко, 2013), как путь, на котором тенденция Я к сохранению «себя» встречает вызовы Я к разотождествлению с собой, к самоизменениям и отождествлению с собой на 
все новых уровнях, в новых ипостасях и свойствах. Самотождество Я в современном, расширенном познавательном контексте может рассматриваться во множестве дополняющих друг друга определений. В частности, самотождество Я - это осознаваемое Я постоянство «себя» во времени, проживание совпадения Я-сам с собой в актах самосознания, реализуемая Я-сам возможность быть собой, изменчивое постоянство самоатрибуции, становление образа «Ясам-для-себя», непрерывность инициирования и интеграции самовыражений в центральной точке «Я-сам» и т.д.

Основываясь на принципе «культурной феноменологии», методах герменевтики и теоретического моделирования, мы выдвигаем и обосновываем идею о внутреннем рефлексивном диалоге Я - Другой как существенном внутриличностном условии достижения самотождества Я. Специфика нашего подхода состояла в выявлении и синтезе многосторонних связей между оппозициями, определяющими парадоксальность генеза самотождества Я и «снимающимися» при его достижении. К этим оппозициям относятся: Я и Другой, реальный Другой и внутренний Другой, самодостаточность Я и необходимость диалогов с другими, самотождественность и разотождествление Я с собой, рефлексия и «взгляд Другого», «Я для себя» и «Я для Другого», изменчивость и устойчивость Я. И хотя в культуре, языке существует множество рефлексивных выражений состояния самотождества, «сводящих» данные оппозиции («С Тобой я чувствую себя самим собой», «Ощущаю, как Твой взгляд возвышает меня», «Лишь изменяясь, я могу узнать неизменное в Себе», «Чтобы встретить Себя, я должен расстаться с собой» и т.д.), целостное теоретическое обоснование «диалектики» достижения самотождества отсутствует.

Основным результатом предпринятого нами концептуального синтеза стала структура развивающего рефлексивного диалога, ориентированного на многомерное самораскрытие Я в отношении к Другому с позиций «Я-сам» и с позиций «внутреннего Другого». Полагаем, что такой диалог может обогащать и усиливать самотождество через проблематизацию, гармонизацию и обобщение репрезентаций Я, полученных с указанных позиций. Авторская идея нашла разработку в виде континуума «герменевтическая модель - теоретическая модель - рефлексивная модель», который служит изучению и актуализации динамики самотождества в его обусловленности внутренним диалогом.

\section{Герменевтическая модель достижения самотождества Я}

Основными источниками разработки герменевтической модели стали философские концепции «индивидуальной личности», представленные в трудах М.М. Бахтина (Бахтин, 1986, 2001), Г. Марселя (Марсель, 2004), Э. Левинаса (1998), П. Рикера (Рикер, 2008), М.К. Мамардашвили (1997), давно ставших культурным достоянием. Спецификой данных произведений в измерении культурной феноменологии является развитие идей о Я личности: о сохранении его целостности и постоянства во времени; о конструктивном и 
деструктивном разотождествлении Я с собой; о значимом Другом как факторе укрепления и проблематизации самотождества личности; о внутреннем диалоге с Другим в форме обращений личности к Я, представленному в Другом, к Другому, представленному в Я, к Мы, конституированному реальным взаимодействием с Другим; о диалогичном характере поддержания самотождества, а также о многих конкретных условиях достижения самотождества Я в его отношении к Другому и самому себе.

Идеи указанных исследователей, наиболее ценные в персонологическом и культурно-феноменологическом планах, были эксплицированы, дополнены результатами наших предшествующих исследований и систематизированы в герменевтической модели, обобщившей существующие позиции в изучении самотождества Я.

1. Фокусом изучения самотождества выступает индивидуальная личность, телесно, душевно и деятельно проживающая жизнь в мире. Становление, изменчивость, динамичная устойчивость личности обусловлены двойственным характером ее бытия и сущности, конфликтами и единством заключенных в них оппозиций. Личность - это «каждый» среди множества других и неповторимая, несравнимая с другими индивидуальность; это обладатель телом, как все иные люди, и уникальным телом, которое нельзя повторить и передать другим; это Я, как все другие Я и единственное, мое «Я-сам»; это Я для самого себя и Другой для всех других людей; это «Я-сам» и «Я как Другой» для себя (Рикер, 2008); это Я и «внутренний Другой» в их представленности в самосознании.

2. Индивидуальная личность в перспективе обретения самотождества рассматривается как включенная в процесс жизненной реализации ценностных отношений к миру, к Другому и к себе. «Жить - значит занимать ценностную позицию в каждом моменте жизни, ценностно устанавливаться» (Бахтин, 1986, с. 173). При занятии ценностных позиций личность ориентирована на поддержание и создание условий для полноценной жизни других людей и исполненности собственного бытия. Этими условиями в многовековой ретроспективе и актуальности человеческой жизни являются: красота, поиск истины, вера, любовь к людям, созидание и усовершенствование сущего, самопознание человека и забота о себе, переживание счастья, встреча и со-бытие с Другим. Эта «ценностная наличность» жизни реализуется человеком через «смысловые отношения» (Бахтин, 1986, 2001): эстетическое, этическое, познавательное, творческое, рефлексивное, диалогичное.

Ценностность индивидуальной жизни устанавливается в природе, социуме, культуре, в кругу других, в общении с конкретным Другим, в обращении к себе. В этих множественных мирах происходит становление отношений как способов активной, осознанной, Я-обусловленной «ценностной причастности» личности. Посредством отношений личность осваивает и преодолевает границы своих миров, приобретая и умножая ценностные опоры самотождества. Особенно это касается мира, откуда Я наиболее хорошо видимо, наблюдаемо и осмыслено, - мира значимого Другого (Мамардашвили, 1997). 
3. Личность исследуется в качестве $\boldsymbol{Я}$, реализующего отношения и достигающего, утрачивающего и вновь обретающего самотождество в процессе жизни. Различаются формы Я, которые в единстве конституируют становление самотождества (Марсель, 2004; Бахтин, 1986, 2001; Рикер, 2008; Мамардашвили, 1997):

- Я-эмпирическое, или реальное, телесное, действующее, выражающее себя в мире; Я - «самопереживание и самоосознание жизни, а следовательно, и самовыражение ее как нечто единое, имеющее свои незыблемые границы, и эти границы пролегают по отношению к собственному внешнему телу» (Бахтин, 2001, с. 109);

- Я как Другой, выступающий в нескольких жизненных аспектах: Я, подобное всем другим Я; Я, выступающее «другим Я» для всех иных Я; Я, отразившее другого человека и имеющего его как часть собственного внутреннего мира; Я, открывшее свою инаковость, или «другость», в сравнении с самим собой;

- Я как Я-сам, отделивший себя в самосознании от Другого, других и от «себя» в движении собственной жизни: единственное, автономное, творческое;

- Я-Абсолютное, или надындивидуальное, бессубъектное, невербальное, не столько познаваемое, сколько постигаемое. Это «критерий очевидности», «критерий жизненности наших состояний» (Мамардашвили, 1997), ядро и опора самотождества, неизвестное измерение жизни, интуиция «себя» как абсолютного существа.

Телесность-другость-самость-абсолютность Я указывают на те «слои» жизни личности, где устанавливается, теряет устойчивость, испытывает изменения и развивается самотождество. В этих «слоях» Я находится в состояниях «достигнутого», «актуального» («наличного») и «возможного», а также как Яизвестного и Я-неизвестного для самого себя (Исаева, 2013; Старовойтенко, 2018). Достижение Я самотождества предполагает установление, удержание, гибкие изменения и восстановление единства между этими состояниями, присущими выделенным выше формам Я, а также формам, или ипостасям, Я, раскрываемым другими моделями (Петровский, 2012, 2013; Старовойтенко, 2015).

4. Учитывается роль конкретного значимого Другого в становлении самотождества Я. Подчеркивается, что развитие Я происходит в явном и неявном присутствии, в виду и под взглядом конкретных других, под внутренним влиянием их знаний, переживаний и представлений о нем, при его встречах с другими по поводу общих предметов деятельности, при передаче ему способов, инструментов и продуктов практических действий.

Другой - объект ценностных отношений личности, их внутренний активный «субъект», а также опосредующее начало в отношении личности к себе. В любом отношении личности - этическом, эстетическом, познавательном, творческом - организующим является ценностное присутствие Другого. Каждое отношение и Я как его самотождественный субъект развиваются, обогащенные «ценностным избытком ви́дения», «трансгредиентным завершением» со 
стороны Другого (Бахтин, 1986, 2001) и при этом открыты для обновления со стороны самого Я.

Другой в контексте отношения к Я и отношения Я к нему способен определять следующие условия постоянства и динамики самотождества Я: получение Я целостного знания о себе; создание Я образа своей телесности, внешности; любовь и уважение Я к себе; сомнение Я в истинности знания о себе; переживание внутреннего существования «неизвестного Я»; настрой мысли Я на расширение, интеграцию «себя» путем включения в новые ценностные отношения в мире с участием Другого: «мир сложен, нужно ломать голову, нужно постоянно заглядывать в себя, менять себя...» (Мамардашвили, 1997, c. 48). Наряду с этим, возможно закостенение представлений Я о себе в связи с постоянством оценок Другого; отвержение Я самого себя благодаря настойчивой акцентировке Другим его негативных свойств.

5. Достижение самотождества Я исследуется как процесс и результат отношения к себе, в котором Я находится в той или иной связи с Другим и осознает себя самого «Другим» в качестве изменчивого объекта самоотношения. Путь к самотождеству в отношении к себе означает множество моментов проживания, фокусирующихся в Я-сам (Левинас, 1998; Марсель, 2004; Мамардашвили, 1997): переживание изначального одиночества; ощущение исхождения из себя и возвращения в себя; признание, что «Я - это неотвратимо Я-сам» (Мамардашвили, 1997, с. 44); прикованность к себе; чувство свободы быть самим собой; переживание, что «Я есть у самого себя»; непрерывное со-бытие с собой; занятие самим собой; осознание совпадения с собой; постижение «предела Я» в соотношении с возможностями других людей; открытие своего индивидуального предназначения в мире. Добавим также, что это пребывание в уединении; обращение к вспоминанию, восприятию, представлению, рефлексии «себя»; ощущение жизненно непрерывной принадлежности своего тела «вот этому Я» и принадлежности своего Я «вот этому телу»; диалог с собой; принятие и осознанная интеграция Я-сам своей «тени» в опыте восполнения и преобразования себя.

Особая роль в достижении самотождества принадлежит «смыслу» как «другому Я», полагаемому личностью в будущей жизни в качестве субъективной возможности и долженствования, или моменту «высшей творческой серьезности», «чистой продуктивности» Я (Бахтин, 1986, 2001). Стремящееся к смыслу творчество в мире и в отношении к себе, предполагая продуктивность, продолженность в других, отклики и ответные вклады других, является в движении к самотождеству и способом необходимого «расставания с собой», и потенциалом «встречи с собой» в новом горизонте.

6. Выявляются риски и потенциалы Я при достижения самотождества в отношении к себе. Основным риском и одновременно возможностью на пути к самотождеству является разотождествление Я с собой. Это несовпадение Я-сам с Я как объектом самоотношения, как объектом отношения Другого, как субъектом отношения к Другому, как отражением во внутреннем мире Другого и как отражением себя в самом себе. Найденное интуитивно и рефлексивно, данное несовпадение может вести к обнаружению и признанию Я 
своих негативных свойств, нежелательных состояний, своих неприемлемых желаний, своих недостойных поступков, саморазрушительных действий или, напротив, открытию своих подлинных сил, дарований, новых достоинств, нереализованных возможностей, неиспытанных жизненных состояний.

Достижение самотождества в направлении развития личности - путь к себе, предполагающий встречу с высоко значимым Я-неизвестным, открытие его сути, постановку творчески-рефлексивной задачи восполнить Я-знаемое, превращение ранее неизвестного Я в активного субъекта сознательной жизни. Можно, однако, чувствовать Я-неизвестное как область «своей неотразимости» для себя и других и оберегать эту «тайну своей индивидуальности» (Петровский, 2009).

При достижении самотождества в отношении к себе неизбежны переживания себя «чужестранцем» для самого себя (Левинас, 1998). «Зияющая различность» Я и себя самого, несовпадение того, что раньше было тождественным, «внутренний раскол» себя требует иногда личного обращения к другим людям, которые могут удостоверить постоянство Я, содействовать жизненно важному соединению разделенного, овладению Я своими конфликтующими сторонами.

Также в своем движении к самотождеству Я может «потеряться» в неизвестности будущего, когда деятельность, ставшая «местом вложения Я», может быть завершена за дальними границами индивидуальной жизни, когда исход дела не может быть интегрирован личностью в историю своего Я. Но возможно, что интенция к «завершению себя» станет для Я общим смыслом деятельного продления своей жизни в бытии мира, культуры, других.

Предельным потенциалом становления самотождества является открытие наилучшего «другого $\boldsymbol{Я » ~ в ~ г л у б и н н о м ~ с л о е ~ о т н о ш е н и я ~ к ~ с е б е ~}$ (Мамардашвили, 1997). Это открытие проживается личностью как прорыв в сознание ее тайной жизни («Я сам себя удивил»), как «чувство переполняющей радости, ощущение другой жизни, другого самого себя» (там же, с. 49). Это разотождествление не требует преодоления, вызывает стремление удержать свою инаковость, но не раствориться в ней, желание узнать ее и испытать себя в обновленном бытийном облике. В отношении к себе равноценны бессознательные и осознанные, тайные и знаемые источники достижения самотождества, встречи с собой «в темноте» и «на свету». В динамике совпадения и разотождествления с собой их единство ничем не может быть заменено.

7. Выделяются основные условия достижения самотождества Я в отношении к себе:

- поддержание связи Я со своим телом: реальное Я «отягощено» телом; встреча и признание себя в мире - это онтологическое событие, в котором выражается вся материальность человека (Бахтин, 1986, 2001);

- принятие Я своего фундаментального одиночества, бытия одиноким субъектом, отягощенным миром, телом; одновременно, постижение, что «действительная человеческая связь возможна только между одинокими людьми» (Мамардашвили, 1997, с. 152); открытие возможностей, связанных с пребыванием «в себе», в уединении, оберегая единственность себя; 
- возложение Я на себя ответственности за самого себя как индивидуальность, глубины которой постигаемы только им самим;

- установление рефлексивной связи с собой как внутреннего отношения Я-субъекта со своим «двойником» - Я-объектом, реальным Я в мире; удвоение бытия в «далеко не безмятежной рефлексии» (Бахтин, 1986, 2001);

- совершение Я собственных активных действий во всегда новых, неопределенных и проблемных, ситуациях, становящихся событиями, которые утверждают самодостаточность и «самостояние» Я в мире;

- творчество, или продуктивный выход Я в мир, возвращение Я к себе в раскрытии тайн бытия и в творческих достижениях; переход Я от сосредоточенности на себе самом к новой реализации себя во множестве своих ипостасей (Марсель, 2004);

- смыслонаправленность Я, или целостный порыв вне-себя-к-своей-ценности; полная осуществленность в этом порыве; действия в адрес ценного объекта; признание миром и другими людьми персонального вклада Я в его бытие; обогащение Я самосознанием исполненного смысла;

- ведение диалога с собой как с Ты, установление диадического отношения, состоящего во внутреннем объединении Я с собой; вне рамок этого отношения Я «объективирует себя», грозя разрушить самотождество (там же);

- обретение любви Другого, что означает утверждение Другим бытия Я, как оно есть; существование Я для любящего Другого в абсолютной единственности: «только Я и никто другой»;

- совершение поступков исполнения Я своей ответственности и обязательств перед Другим, в которых Я переживает и осознает верность себе и полноту «себя»;

- вскрытие Я противоречий отношения к себе; их образуют множество оппозиций, требующих от Я уравновешивания, или исключения, или синтеза для поддержания самотождества: активность самосознания - слабость осознания себя, совпадение - несовпадение собственного знания личности о себе и знания о ней других, однородность - расхождение самооценки и оценки другими, согласованность - рассогласование внутренних интенций Я к действиям и характера его внешних действий, единство - раскол внутреннего ви́дения себя и восприятия себя во внешней жизни, гармония - разделенность воображаемого и реального Я или Я-наличного и Я-возможного;

- тождество Я самому себе, «расставание» Я с самим собой и новое соединение с собой дается личности в общих самопереживаниях: удовлетворенности - недовольства собой, уверенности - сомнения в себе, возможности невозможности быть собой, радости - печали самобытия, понимания - непонимания себя, принятия - отвержения себя, выбора - отказа от себя.

8. Самотождество Я изучается как достигаемое в отношении Я к Другому: «Никто не может оставаться в себе самом: бытие человека человеком, субъективность есть предельная ответственность за другого человека» (Левинас, 1998, с. 239). Отношение личности к себе и достижение самотождества в его контексте невозможны вне связей с отношениями к значимым другим. Отношение к значимому Другому в процессе становления и активной реализации 
Я-субъектом приобретает множество «ценностных коэффициентов» (Бахтин, 1986, 2001) - эстетический, этический, интеллектуальный, творческий, рефлексивный, диалогический, вбирая влияние многих ценностных отношений личности.

9. Выделяются следующие условия достижения самотождества Я в отношении к Другому (Марсель, 2004; Левинас, 1998; Бахтин 1986, 2001):

- подлинность отношения, в которое сознательно, творчески, деятельно вступает Я, чтобы инаковость Другого не поглотила и не подавила Я;

- реализация межсубъектной связи для преодоления своего экзистенциального одиночества и одиночества Другого;

- освоение пространства другости - мира того, что не есть Я;

- объединение Я с Другим на основе предмета, равно значимого для обоих, притягивающего к себе активность каждого и их продуктивное содействие;

- приобретение равенства позиций: один для другого то же самое, что другой для него, переживание близости «без посредников», амплификация, укрепление Я за счет многомерного единства с Другим в различных «измерениях» отношения к Другому (Старовойтенко, 2013, 2017; Starovoytenko, 2018)b;

- вненаходимость Я и Другого, определяемая ситуациями видения друг друга, обращения друг к другу, взаимодействия друг с другом, рефлексии внешнего и внутреннего соприсутствия в жизни друг друга (Я в измерении межәу-Я-и-Другим);

- занятие Я рефлексивной позиции между собой и Другим, освещая себя и «затеняя» собой реальность, что требует от Я погружения в мир Другого и возврата в-себя, будучи «пронизанным» его бытием (Я в измерении $\boldsymbol{Я - \boldsymbol { в } -}$ себе);

- вхождение Я во внутренний диалог с Другим как в событие творчества, исключающее власть Я и Другого, устанавливающее равенство их позиций, утверждающее ценность любой позиции Я и Другого, исключающее отождествление Я с Другим и Другого с Я, при котором отношения невозможны (Я в измерении между-Я-и-Другим);

- погружение Я в жизнь Другого, помещение себя на его место, взгляд на себя его глазами, что позволяет «рассеять по крайней мере на несколько мгновений собственную одержимость самим собой» (Марсель, 2004, с. 42), открытие «себя» в мире Другого (Я в измерении $\boldsymbol{Я - в - Д р у г о м ) ; ~}$

- осознание Я присутствия Другого внутри себя, но не как вторжения извне, а как значимой внутренней реальности, как Ты, заслуживающей открытости и доверия (Я в измерении Другой-в-Я);

- связь Я с Другим, когда он не просто сотрудничает, действует вместе с Я в мире, а выступает внутренним собеседником (Я в измерении Другой-в-Я);

- внутреннее приближение Другого, который оказывается в кругу ответственности Я, и благодаря этому нечто уже «выходит за пределы свободно принимаемых Я решений» (Левинас, 1998), ослабляя, но в перспективе усиливая, его самотождество (Я в измерении Другой-в-Я); 
- пребывание Я в качестве Ты для Другого, не потерявшись в нем, не подпав под его власть, избежав искажения себя, измены себе, чуждости себе, порабощенности этим иным, разрыва близости с ним; передача ответственности Другому за себя, которая позволила бы ему встать на место Я и понять его

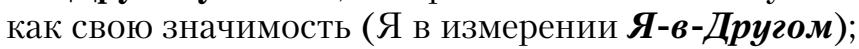

- возвращение Я к самому себе, соединение с собой, преодоление «неудачи себя» в инаковости Другого (там же) и овладение «новизной себя» в при-

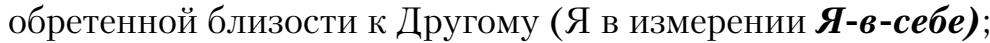

- внимание Я к «фону за своей спиной» (Бахтин, 1986, 2001), непосредственно недоступному ему, но на котором его как единое целое воспринимают значимый Другой и окружающие Я и Другого люди (Я в измерении $\boldsymbol{Я}$-в мире-с-Другим);

- обобщение Я «в себе» ценностных отражений своего отношения к

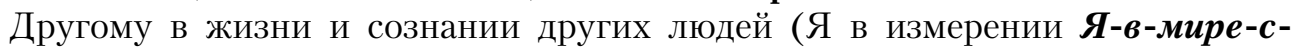
Другим).

10. Самотождество Я изучается как становящееся в рефлексивном диалоге Я - Другой или самопознании и артикулировании «себя» во внутреннем взаимодействии с Другим, в своей представленности в Другом и своей относительной автономии от Другого. Реальный значимый Другой приобретает, благодаря рефлексии, качество осознанного «внутреннего Другого», знаемого «внутреннего собеседника», необходимого «моего Другого», диалог с которым становится «страстной встречей с самим собой» (Мамардашвили, 1997). Рефлексивный диалог, являясь одной из форм внутреннего диалога, выступает важнейшим способом достижения самотождества и становления Я в качестве «диалогического» (Hermans, Kempen 1993, Hermans, 2001; Старовойтенко, 2017).

Я в движении к самотождеству не может создать себя, «стать самим собой», «заново родиться», «уплотниться в нечто целое» (Бахтин, 1986, 2001) только своими силами. На этом пути нужно внешнее и внутреннее присоединение Другого, значительно увеличивающее для Я степени свободы в проявлении себя, в поворотах себя различными сторонами к другому человеку, в получении от него откликов и ответной активности, в синтезе аспектов «себя», умножающихся во взаимодействии с Другим. В диалоге с Другим и реализации диалогических позиций Я должен полагать себя уже состоявшимся (достигнутым), актуально живущим (наличным) и себя еще предстоящим самому себе (возможным). Во внутреннем диалоге Я может занимать разнообразные положения относительно себя и Другого, укрепляющие его идентичность с собой: «рядом», «напротив», «вместе», «между», «в Другом», «с Другим», «вместо Другого», «в себе», «в качестве Другого». В богатстве этих положений, а также диалогичных Я-позиций проживание самотождества получает опоры, поддерживающие его в ситуациях неизбежных жизненных изменений Я и утрат его идентичности с собой.

Движение внутреннего диалога в направлении развития самотождества требует от Я встать в отношение Я - Другой как отношение «внутренней вненаходимости и противонаходимости» (Бахтин, 1986, 2001), рефлексивно раскрыть 
Я в измерениях «между-Я-и-Другим», «Я-в-Другом», «Другой-в-Я», «Я-всебе», «Я-в-мире-с-Другим». Я амплифицируется в смене множества Ярепрезентаций, в обнаружении расхождений или противоречий репрезентаций Я и репрезентаций Другого в разных измерениях, в нахождении и применении способов внутреннего и внешнего согласования, синтеза этих репрезентаций и разрешения их противоречий, в прохождении рефлексивного пути от относительного самотождества до разотождествления с собой и к вновь достигнутому самотождеству. Полагаем, что усиление Я во внутреннем диалоге может приобретать дополнительную интенсивность за счет осуществления рефлексии не только с позиций Я, но и с позиций внутреннего Другого, что придает больший объем диалогу, получающему в каждом рефлексивном измерении и в их целом тонкость дефиниции «для Я» - «для Другого». Здесь самотождество и диалогичность Я вступают во взаимно развивающие отношения: самотождество достигается на основе приобретения Я диалогичности; диалогичность возможна для самотождественного Я; в моментах разотождествления с собой и утраты диалогичности Я приобретает импульс к новому движению к самотождеству и реализации потенциала своей диалогичности (Старовойтенко, 2017; Starovoytenko, 2018b). Самотождественное, диалогичное Я утверждает бытие значимого Другого, удерживая внутреннего Другого в поле активного сознания и переживания, придерживаясь границ измерений отношения к нему, осознавая его внутренний «взгляд» на себя, возвращаясь к реальному взаимодействию с ним в мире, вновь «овнутряя» его, обогащенного взаимными вкладами с Я, увеличивая «вес» его продуктивного присутствия в Я-сам.

Рефлексивный диалог Я-сам со своим внутренним Другим как аспектом Я и одновременно с Другим как автономно существующей личностью отражает и включает множество событий:

- взаимодействие Я и Другого, совместную активность тел с их практическими, коммуникативными и эстетическими функциями;

- отношение одного сознания к другому сознанию именно как к другому творческое, продуктивное событие, «новое несущее, единственное и необратимое» (Бахтин, 1986, 2001);

- переживания в адрес друг друга, которые, протекая вне Я в реальном Другом, имеют обращенную к Я «внутреннюю внешность», доступную созерцанию, а протекая в Я, предстают для Другого посланием, которое он может прочесть как «внешнюю внутренность»;

- называние имен друг друга, вопрошание друг друга, ожидание ответов друг друга, авторитетные высказывания в адрес друг друга, подтверждения или отрицания каждым говорящим слов, сказанных другим о себе;

- реализацию друг другом своих ценностных позиций, порождающих смыслы текстов диалога, которые участвуют в образовании «предстоящего» жизненного смысла Я - главного призыва и вызова для его самотождества;

- оформление души в самотождественное Я извне, другим телом, другим сознанием, текстом другого, без чего внутренняя жизнь Я не может «уплот- 
ниться в какую-то определенность», а является лишь «разрозненной субъективностью» (Бахтин, 1986, 2001);

- становление «взаимности» посредством переноса и активности образа Другого в Я, открытия Я незаменимого характера своей жизни в Другом и для Другого, а также путем оценки Другого как самого себя, которая для Я эквивалентна оценке себя как Другого (Рикер, 2008);

- сохранение внешней и внутренней вненаходимости по отношению к Другому, позволяющее ценить его автономию, целостность, широту и оформленность его границ. При этом «уверенное и обоснованное создание и обработка границ, внешних и внутренних, другого человека и его мира предполагают прочность и обеспеченность позиции вне его, позиции, на которой субъект может длительно пребывать, владеть всеми своими силами и свободно действовать....» (Бахтин, 1986, с. 187);

- понимание относительности «диалога» Я - Другой в связи с тем, что «всегда есть Третий», т.е. другие, общество, культура, создающие возможность для Я реализовать в полноте свои ценностные позиции, что требует выйти из диалога и встать над ним для придания ему избыточного, продуктивного качества как нового ресурса Я-сам.

11. Самотождество Я исследуется во множестве феноменов проживания, возникающих в опыте индивидуального постижения, именования и рефлексии «совпадения с собой» (Марсель, 2004; Левинас, 1998; Мамардашвили, 1997). Эти феномены могут свидетельствовать как о самотождестве, способствующем развитию Я, так и о самотождестве, блокирующем это развитие.

$\mathrm{B}$ «отношении к себе» и «отношении к Другому» к феноменам «развивающего самотождества» можно отнести: чувство себя внутри собственной жизни; стремление Я быть этим самым Я; осознание своей автономии; потребность быть собой; принятие себя; согласие с собой; владение собой; чувство близости себя; уважение к себе; счастье быть собой, любовь к себе; переживание Я-неизвестного в себе; чувство непрерывности себя; уверенность, что можно положиться на себя; переживание постоянства себя; удовлетворенность собой; управление собой; обладание смыслом собственного бытия; переживание себя как опоры своей жизни; чувство преодоления своего «еще не бытия»; стремление быть себе другом; отказ от себя ради достижения своего нового Я; чувство возможностей Я; переживание подлинности своей жизни; любовь к себе в отражении любви Другого; переживание обретения себя в признании таланта Другого; «бег от Другого» для встречи с собой; стремление стать собой, продолжая Другого; восполнение «себя» осознанным признанием и вкладами со стороны Другого; чувство своего бытия в Другом; открытие своего Я как творения Другого; создание самого себя.

«Деструктивное самотождество» связывается с застывшими представлениями Я о себе, с отрицанием существования Я-неизвестного, с отсутствием любопытства, любознательности, сомнения и проблематизации при осознании себя, со слабостью рефлексии, с подменой собственного знания «себя» знанием, транслируемым другими, с идеализацией себя, не допускающей бинарности собственных свойств, с акцентированием темных сторон своего Я, 
исключающим позитивный взгляд на себя. Феноменами проживания самотождества в данном случае могут выступать: поглощенность собой, замкнутость на себе, изоляция в самом себе; плененность собой, заполненность собой, чувство навязанности самому себе, заключенность в самом себе, одержимость собой, чувство грандиозности Я.

12. Достижение самотождества рассматривается как смена состояний совпадения и разотождествления с собой. Разотождествление может необратимо нарушать единство Я-субъекта и Я-объекта сознания, может вести к полной потере Я-субъектности, образованию непроходимых границ между различными ипостасями Я, растворению Я во внешнем объекте проективной идентификации (Гротштейн, 2017), к вытеснению отвергаемой части Я, может вызвать непреодолимые расхождения собственных репрезентаций Я с представлениями о Я других людей, атаки сознания на те или иные аспекты Я, отчуждение части Я в другого человека, отрицание своих негативных свойств, потерю «себя» в жизненной перспективе.

Однако разотождествление может быть и закономерным эффектом рассогласования устоявшихся и нарождающихся свойств Я, признаком возникновения развивающих противоречий между оппозиционными сторонами Я, знаком рождения новых аспектов Я, способом проблематизации Я достигнутого уровня своего развития и поиска путей выхода на его более высокие уровни. Здесь разотождествление становится условием перехода Я на новый этап достижения самотождества.

В общей динамике самотождества различные формы разотождествления с собой могут субъективно проживаться как отделение от себя, забывание себя, неузнавание себя, освобождение от себя, отречение от себя, борьба с собой, невозможность быть собой, невоссоединение с собой, бег от себя, отстранение от себя, потеря себя, обнаружение «чужого себя», возможность встречи с собой-другим. Распространенность и субъективная достоверность проживания разотождествления личности с собой позволяют исследователям помыслить об «иллюзорности», «кажимости» самотождественного Я.

Приведенная герменевтическая модель достижения самотождества Я может найти преломление в частном теоретическом или эмпирическом исследовании либо в развивающей практике. При этом она конкретизируется, «сгущается» в авторских моделях, ориентированных на решение определенных исследовательских задач. В нашей работе это теоретическое акцентирование внутреннего диалога Я - Другой как средоточия условий достижения самотождества Я, разработка структуры рефлексивного диалога личности, построение проекта рефлексивной практики, служащей актуализации процессов поддержания и проблематизации самотождества Я.

\section{Теоретическая и рефлексивная модели достижения самотождества Я во внутреннем диалоге}

Теоретическая модель строится путем концентрации идей герменевтической модели, обосновывающих наш подход к изучению самотождества Я. Она 
включает определение условий достижения самотождества Я с акцентом на внутренний диалог; структуру бинарных Я-репрезентаций с позиций «Я-сам» и «Другого» в рефлексивном диалоге Я - Другой; критерии оценки Я-репрезентаций во внутреннем диалоге с точки зрения поддержания самотождества Я и появления моментов разотождествления с собой.

\section{Условия достижения самотождества Я}

- Личность приобретает самотождество, реализуя жизненные отношения, в частности отношение к конкретному значимому Другому. В числе множества ценностных аспектов становления данного отношения большое значение имеет его рефлексивно-диалогичное развитие.

- Личность при достижении самотождества в отношении к Другому выступает в качестве Я-сам, имеющего множество ипостасей, в качестве субъекта и объекта самоотношения в контексте отношения к Другому, в качестве Я как результата непрерывного жизненного движения от Я-достигнутого к Яактуальному и к Я-возможному.

- Необходимыми моментами жизненной динамики самотождества являются состояния совпадения Я с собой и состояния разотождествления Я с собой в контексте внешнего и внутреннего отношения к Другому.

- Значительными возможностями для достижения самотождества Я обладает внутренний диалог Я - Другой. В данном диалоге как способе реализации отношения к Другому происходит самоопределение Я как субъекта диалога, «заимствование» своего Я у Другого, «овладение» Я внутренним Другим, обретение Я аутентичности в относительной свободе от Другого, полагание Другого как свободного субъекта диалога в составе Мы.

- Внутренний диалог Я - Другой является обращением личности к значимому Другому, представленному в ее внутреннем мире в качестве действующего, взаимодействующего, говорящего, неповторимо отражающего (в образе, мысли, переживании) Я, индивидуально отраженного в Я, занимающего свою позицию в диалоге, рефлексирующего.

- Отношение Я к Другому имеет ряд взаимодополняющих измерений, характерных и для пространства внутреннего диалога. Это измерения междуЯ-и-Другим, Я-в-Другом, Другой-в-Я, Я-в-себе, Я-в-мире-с-Другим. Становлению самотождества Я может способствовать рефлексивная амплификация Я через обращения к себе и репрезентации Я в каждом и во всех измерениях внутреннего диалога. Речь идет о рефлексии Я - между-Я-иДругим, Я - Я-в-Другом, Я - Другой-в-Я, Я - Я-в-себе, Я - Я-в-мире-сДругим. Внутренний диалог приобретает качество «рефлексивного», порождая множество эффектов самопознания Я (Я-репрезентаций) в своих различных измерениях.

- Я-репрезентации, рождающиеся в различных измерениях рефлексивного диалога, могут быть оппозиционными по признакам известности-неизвестности Я, выраженности-невыраженности определенных ипостасей Я, высокой-низкой ценностной насыщенности, позитивности-негативности самопереживания, 
продуктивности-непродуктивности в аспекте интенций к самоизменениям. Совпадение, единство Я-репрезентаций в разных измерениях диалога свидетельствует о направленности личности на поддержание самотождества. Осознаваемые противоречия Я-репрезентаций проблематизируют самотождественность личности, побуждают ее к разотождествлению с Я-достигнутым и поиску конструктивного разрешения противоречий: уравновешивания, синтеза, взаимодополнения Я-оппозиций.

- Возможности достижения самотождества в рефлексивном диалоге Я Другой могут быть умножены за счет осуществления рефлексивных действий в различных измерениях диалога с позиций «Я-сам» и с позиций «Другого» за счет порождения бинарных Я-репрезентаций «для Я» и «для Другого» и их интеграции. Таким путем может происходить укрупнение, увеличение объема диалога с соответствующим ростом потенциала укрепления, а также проблематизации самотождества с последующим творческим развитием Я.

Ниже представлена структура бинарных Я-репрезентаций, «запускающих» движение рефлексивного диалога Я - Другой в аспекте обнаружения личностью согласования, рассогласования, возможностей интеграции эффектов рефлексии друг с другом

Структура бинарных Я-репрезентаций в рефлексивном диалоге Я-Другой

\section{Я-репрезентации с позиций Я-сам} между-Я-и-Другим-для-Я

$$
\text { Я-в-Другом-для-Я }
$$

Другой-в-Я-для-Я

Я-в-себе-для-Я

Я-в-мире-с-Другим-для-Я

\section{Я-репрезентации с позиций Другого}

между-Я-и-Другим-для-Другого

Я-в-Другом-для-Другого

Другой-в-Я-для-Другого

Я-в-себе-для-Другого

Я-в-мире-с-Другим-для-Другого

\section{Критерии оценки Я-репрезентаций во внутреннем диалоге}

Обнаружению динамики самотождества Я во внутреннем диалоге служат критерии оценки Я-репрезентаций, касающиеся в основном качественных характеристик рефлексии и относящиеся к Я-репрезентациям во внутреннем диалоге в целом и к бинарным Я-репрезентациям с позиций Я-сам и Другого в отдельных измерениях диалога:

1) осознание - неосознание относительной автономии Я-сам и внутреннего Другого; 
2) доступность - недоступность позиции внутреннего Другого;

3) опора на Я-сам - опора на Другого в Я-репрезентациях;

4) известность- неизвестность «себя» в Я-репрезентациях;

5) позитивное - негативное переживание себя в Я-репрезентациях;

6) актуальность - возможность «себя» в Я-репрезентациях;

7) знание - незнание себя в бинарных Я-репрезентациях;

8) выраженность - невыраженность ценностных характеристик Я в бинарных Я-репрезентациях;

9) удовлетворенность - неудовлетворенность Я собой в бинарных Ярепрезентациях;

10) продуктивность - непродуктивность Я в плане самоизменений в бинарных Я-репрезентациях;

11) проживание - непроживание Мы в бинарных Я-репрезентациях;

12) убеждение - сомнение в постоянстве Я в ходе рефлексивного диалога.

С помощью данных критериев определяются совпадения, рассогласования или противоречия Я-репрезентаций по разным параметрам в измерениях внутреннего диалога в целом, а также совпадения, рассогласования или противоречия Я-репрезентаций с позиций Я-сам и Другого в разных измерениях диалога.

Например, в состоянии рассогласования находятся следующие Я-репрезентации, относящиеся к измерениям рефлексивного диалога между-Я-иДругим и Я-в-Другом: Я нравлюсь себе, взаимодействуя с Другим - Я не нравлюсь себе в своем отражении в Другом (критерий 5).

Или оппозиционными являются следующие Я-репрезентации, относящиеся к измерениям рефлексивного диалога между-Я-и-Другим и Я-в-мире-сДругим: Я знаю себя в своем взаимодействии с Другим, но мне неизвестно, как Я с Другим представлены в мире для многих других (критерий 4).

Или могут заключать противоречие следующие Я-репрезентации, относящиеся к измерению Я-в-Другом, сделанные с позиции Я-сам и с позиции Другого: Я стремлюсь изменить к лучшему мысли Другого обо мне, но для Другого я остаюсь неизменным (критерий 10).

Или рассогласованными выступают следующие Я-репрезентации, относящиеся к измерению Другой-в-Я и сделанные с позиции Я-сам и Другого: Для меня Другой является надежньм другом, однако в представлениях Другого это еще только должно произойти (критерий 8).

Самотождество Я конкретной личности во внутреннем диалоге может конституироваться самыми различными связями Я-репрезентаций, начиная от их единства до конфликта, требующего разрешения как в направлении укрепления самотождественности, так и в направлении развивающего разотождествления с собой и последующего достижения нового самотождества.

На основе приведенной структурной модели внутреннего диалога Я Другой могут быть разработаны частные, дополняющие друг друга рефлексивные практики, которые развивают, испытывают и проблематизируют самотождество Я. Они могут актуализировать рефлексию, переживание и 
интуицию, адресованную определенным измерениям внутреннего диалога, акцентировать самопознание с позиций Я-сам или Другого, апеллировать к разным содержаниям и качественным характеристиками самопознания. При их применении Я может становиться все глубже раскрываемым объектом и субъектом, реализующим множество внутренних действий, источником которых является он сам. Создаются возможности для расширения внутреннего пространства самотождества, где полноте и единству «Я-сам» непрерывно посылает вызовы Я в своем динамичном отношении к Другому.

Например, модель рефлексии может быть ориентирована на Я-репрезентации во внутреннем диалоге Я - близкий Другой, в измерении Я-в-Другом, с позиции Я-сам и с позиции Другого, раскрывающие знание - незнание себя, удовлетворенность - неудовлетворенность собой, продуктивность - непродуктивность в самоизменениях. Рефлексия моделируется в форме континуума вопросов Я к себе, вызывающих вербальные Я-репрезентации внутренних отношений Я к Другому и Другого к Я, в частности:

Есть ли в моей жизни человек, которого я могу назвать Близким? Кто он?

Есть ли у меня опьт внутреннего общения с ним? Вижу ли я в Близком своего постоянного внутреннего собеседника?

Переживаю ли я свою значимость для Близкого, ощущаю его внимание кмоей внутренней жизни? Знает и понимает ли он меня?

Что мне известно о мыслях и чувствах Близкого по отношению ко мне? Что мне неизвестно об этом?

Что, на взгляд Близкого, мне известно и неизвестно о его мыслях и чувствах, касаюшихся меня?

Удовлетворен ли я тем, как представляет меня Близкий?

Удовлетворен ли я, с точки зрения Близкого, его представлениями обо мне?

Удается ли мне изменять представления Близкого обо мне?

Изменяю ли я, на взгляд Близкого, его представления обо мне?

Чувствую ли я себя самим собой в әтом внутреннем общении с Близким?

Данная рефлексивная практика может выступить фрагментом более полной модели рефлексии, предоставляющей Я больше возможностей утвердить свое самотождество, почувствовать его движение, достичь его нового уровня.

Резюмируя, подчеркнем, что культурно-феноменологические координаты исследования самотождества Я позволяют, отталкиваясь от традиций его познания в философской научной культуре, прийти к новым концептуальным построениям в психологии личности. Предложенная персонологическая модель достижения самотождества Я ориентирована на развитие рефлексии в плане расширения возможностей Я для встреч, поисков и открытий себя.

\section{Литература}

Андреева, Г. М. (2009). Личность в поисках идентичности в глобальном мире. В кн. Г. М. Андреева, Социальная психология сегодня: поиски и размышления (с. 109-115). М.: МПСИ.

Бахтин, М. М. (1986). Эстетика словесного творчества. М.: Искусство. 
Бахтин, М. М. (2001). Автор и герой: К философским основам гуманитарных наук. СПб.: Азбука.

Белинская, Е. П. (2018). Современные исследования идентичности: от структурной определенности к процессуальности и незавершенности. Вестник Санкт-Петербургского университета. Психология и педагогика, 8(1), 6-15.

Гадамер, Х. Г. (1988). Истина и метод: основы философской герменевтики. М.: Прогресс.

Гротштейн, Д. С. (2017). Расщепление и проективная идентификация. М.: Институт общегуманитарных исследований.

Гуссерль, Э. (1999). Идеи к чистой феноменологии и феноменологической философии (т. 1). М.: Дом интеллектуальной книги.

Зарецкий, Ю. П. (2007). Самоидентификация или «моделирование Я». Постклассический концепт субъективности в историографии. В кн. А. А. Саванидзе, П. Ю. Уваров (ред.), Социальная идентичность средневекового человека (с. 9-21). М.: Наука.

Исаева, А. Н. (2013). Знаемое и незнаемое «Я» в значимой жизненной ситуации. Мир психологии, 74(2), 85-96.

Кун, Т. (2002). Структура научных революиий. М.: АСТ.

Левинас, Э. (1998). Время и Другой. СПб.: Высшая религиозно-философская школа СанктПетербурга.

Леонтьев, Д. А. (2009). Лабиринт идентичностей: не человек для идентичности, а идентичность для человека. Философские науки, 10, 5-10.

Мамардашвили, М. К. (1997). Психологическая топология пути. М. Пруст «В поисках утраченного времени. СПб.: Русский Христианский гуманитарный институт.

Марсель, Г. (2004). Опьт конкретной философии. М.: Республика.

Мотрошилова, Н. В. (1968). Принципь и противоречия феноменологической философии. М.: Высшая школа.

Петровский, В. А. (2009). Индивидуальность: саморегуляция и состоятельность. В кн. В. Д. Шадриков, Е. Б. Старовойтенко (ред.), Психология индивидуальности: новые модели и концепции (с. 219-266). М.: МПСИ.

Петровский, В. А. (2012). Я в мысли и Я наяву: как возможно существование Я? В кн. В. Н. Порус (ред.), Проблема «Я»: философские традищии и современность (с. 195-223). М.: Альфа-М.

Петровский, В. А. (2013). «Я» в персонологической перспективе. М.: Издательский дом НИУ ВШЭ.

Петровский, В. А., Старовойтенко, Е. Б. (2012). Наука личности: четыре проекта общей персонологии. Психология. Журнал Высшей школь экономики, 9(1), 21-39.

Рассказова, Е. И., Тхостов, А. Ш. (2012). Идентичность как психологический конструкт: возможности и ограничения междисциплинарного подхода. Психологические исследования, 5(26), 2. Режим доступа: http://psystudy.ru

Рикер, П. (1995). Конфликт интерпретаций: очерки о герменевтике. М.: Медиум.

Рикер, П. (2008). Я-сам как другой. М.: Изд-во гуманитарной литературы.

Старовойтенко, Е. Б. (2013). Достижение себя в отношении к Другому. Мир психологии, 74(2), $71-85$.

Старовойтенко, Е. Б. (2015). Персонология: жизнь личности в культуре. М.: Академический проект.

Старовойтенко, Е. Б. (2016). Генез Я в отношении к Другому. В кн. М. И. Воловикова, А. Л. Журавлев, Н. Е. Харламенкова (ред.), Психологические исследования личности: история, современное состояние, перспективы (с. 117-135). М.: Институт психологии РАН. 
Старовойтенко, Е. Б. (2018). Я-неизвестное в отношениях личности к себе и Другому. Мир психологии, 3, 35-49.

Старовойтенко, Е. Б. (2017). Продуктивность диалогичного отношения Я - Другой. Психология. Журнал Высшей школы экономики, 14(3), 408-432.

Туровский, М. Б. (1997). Феноменологическая концепция культуры. Философские основания культурологии. М.: РОССПЭН.

Шпет, Г. (1996). Явление и смысл: феноменология как основная наука и ее проблемы. Томск: Водолей.

Эриксон, Э. (1996). Идентичность: юность и кризис. М.: Прогресс.

Ссылки на зарубежные источники см. в разделе References после англоязычного блока.

Старовойтенко Елена Борисовна - руководитель центра фундаментальной и консультативной персонологии, департамент психологии, факультет социальных наук, Национальный исследовательский университет «Высшая школа экономики», доктор психологических наук, профессор.

Сфера научных интересов: методология психологии, теоретическая психология личности, персонология, психология жизненных отношений личности, культурная психология личности, психология познания, психология рефлексии.

Контакты: heletstaOS@yandex.ru

\title{
Self-Identity of the I in Internal Dialog
}

\section{E.B. Starovoytenko}

${ }^{a}$ National Research University Higher School of Economics, 20 Myasnitskaya Str., Moscow, 101000, Russian Federation

\begin{abstract}
The study presented in this article is based on the definition of science as a cultural phenomenon, offered by T.S. Kuhn. This approach enables the treatment of psychology of personality and general personology as an open world of cultural phenomena such as productive ideas and theories, models and scientific facts, methods and practices, interpretations and communications. The genesis and potential of these phenomena can be discovered by the cultural phenomenology of the personality. Using methods of hermeneutics, modelling and building of reflexive practices which are relevant to cultural methodology of personality, the author proposes the idea of the internal dialog I - Other as a significant intrapersonal condition in developing the self-identity of the I. In understanding self-identity its achievement is emphasized as a path where the trend of the I to preserve itself meets with challenges of unidentification with self and further identification at new levels. A structure is offered for developing dialog oriented towards the multilevel reflective opening of the I in relation to the Other from positions of the I and the internal Other. It is shown that such a dialog can enrich and strengthen the self-identity of the I through harmonization, problematization and synthesis of I-representations obtained from the above positions. The author's idea has been developed as a continuum: hermeneutical model - theoretical
\end{abstract}


model - reflective model. It addresses the task of studying and actualizing the opportunity to achieve the self-identity of the I in internal dialog.

Keywords: personology, cultural phenomenology, model, personality, the I, Other, internal dialog, self-identity of the I, achievement of self-identity, unindentification with self, reflection.

\section{References}

Andreeva, G. M. (2009). Lichnost' v poiskakh identichnosti v global'nom mire [Personality searching for an identity in the global world]. In G. M. Andreeva, Sotsial'naya psikhologiya segodnya: poiski i razmyshleniya (pp 109-115). Moscow: MPSI. (in Russian)

Bakhtin, M. M. (1986). Estetika slovesnogo tvorchestva [Aesthetics of verbal creativity]. Moscow: Iskusstvo. (in Russian)

Bakhtin, M. M. (2001). Avtor i geroi: K filosofskim osnovam gumanitarnykh nauk [The author and the hero: to the philosophical foundations of humanities]. Saint Petersburg: Azbuka. (in Russian)

Belinskaya, E. P. (2018). Modern identity studies: from structural certainty to procedural and incompleteness. Vestnik Sankt-Peterburgskogo Universiteta. Psikhologiya i Pedagogika, 8(1), 6-15. (in Russian)

Erikson, E. (1996). Identichnost': yunost' i krizis [Identity: youth and crisis]. Moscow: Progress. (in Russian)

Gadamer, H.-G. (1988). Istina i metod: osnovy filosofskoi germenevtiki [Truth and method: the basics of philosophical hermeneutics]. Moscow: Progress. (in Russian)

Gallagher, S. (1992). The theater of personal identity: From Hume to Derrida. Personalist Forum, 8(1), 22.

Grotshtein, D. S. (2017). Rasshcheplenie i proektionaya identifikatsiya [Dissociation and projective identification]. Moscow: Institut obshchegumanitarnykh issledovanii. (in Russian)

Hermans, H. J. M., (2001). The dialogical Self: Toward a theory of personal and cultural positioning. Culture and Psychology, 7(3), 243-281.

Hermans, H. J. M., \& Kempen, H. J. G. (1993). The dialogical Self: Meaning as movement. San Diego, CA: Academic Press.

Husserl, E. (1999). Idei $k$ chistoi fenomenologii i fenomenologicheskoi filosofii [Ideas for pure phenomenology and phenomenological philosophy] (Vol. 1). Moscow: Dom Intellektual'noi knigi. (in Russian)

Isaeva, A. N. (2013). Znaemoe i neznaemoe "Ya" v znachimoi zhiznennoi situatsii [The known and unknown I in a meaningful life situation]. Mir Psikhologii, 74(2), 85-96. (in Russian)

Jaromowic, M. (1998). Self-We-Others schemata and social identifications. In S. Worchel, J. F. Morales, D. Paez, \& J. Deschamps (Eds.), Social identity: International perspective (pp. 44-52). New York: Sage.

Kuhn, T. (2002). Struktura nauchnykh revolyutsii [The structure of scientific revolutions]. Moscow: AST. (in Russian)

Leontiev, D. A. (2009). Labirint identichnostei: ne chelovek dlya identichnosti, a identichnost' dlya cheloveka [The labyrinth of Identities: not a person for an identity, but an identity for a person]. Filosofskie nauki, 10, 5-10. (in Russian) 
Levinas, E. (1998). Vremya i Drugoi [Time and the Other]. Saint Petersburg: Vysshaya religioznofilosofskaya shkola. (in Russian)

Mamardashvili, M. K. (1997). Psikhologicheskaya topologiya puti. M. Proust "V poiskakh utrachennogo vremeni" [Psychological topology of the path. M. Proust "In Search of Lost Time"]. Saint Petersburg: Russkii Khristianskii gumanitarnyi institut. (in Russian)

Marsel, G. (2004). Opyt konkretnoi filosofii [An experience of specific philosophy]. Moscow: Respublika. (in Russian)

Mikhailovskii, A. V. (2012). Sub"ektivnost' i identichnost' [Subjectivity and identity]. Moscow: HSE Publishing House. (in Russian)

Motroshilova, N. V. (1968). Printsipy i protivorechiya fenomenologicheskoi filosofii [Principles and contradictions of the phenomenological philosophy]. Moscow: Vysshaya shkola. (in Russian)

Petrovsky, V. A. (2009). Individual'nost': Samoregulyatsiya i sostoyatel'nost' [Individuality: Self-regulation and subjectness]. In V. D. Shadrikov \& E. B. Starovoytenko (Eds.), Psikhologiya individual'nosti: novye modeli $i$ kontseptsii [The psychology of individuality: New models and concepts] (pp. 219-266). Moscow: MPSI. (in Russian)

Petrovsky, V. A. (2012). Ya v mysli i Ya nayavu: kak vozmozhno sushchestvovanie Ya? [The I in thought and the I in reality: how is the existence of the I possible?]. In V. N. Porus (Ed.), Problema "Ya": filosofskie traditsii i sovremennost' (pp. 195-223). Moscow: Alfa-M. (in Russian)

Petrovsky, V. A. (2013). "Ya" v personologicheskoi perspektive [The "I" in the personological perspective]. Moscow: HSE Publishing House. (in Russian)

Petrovsky, V. A., \& Starovoytenko, E. B. (2012). The science of personality: Four projects of general personology]. Psychology. Journal of the Higher School of Economics, 9(1), 21-39. (in Russian)

Rasskazova, E. I., \& Tkhostov, A. Sh. (2012). Identity as a psychological construct: possibilities and limitations of the interdisciplinary approach. Psikhologicheskie Issledovaniya, 5(26), 2. Retrieved from: http://psystudy.ru (in Russian)

Ricœur, P. (1995). Konflikt interpretatsii: ocherki o germenevtike [The conflict of interpretations: essays on hermeneutics]. Moscow: Medium. (in Russian)

Ricœur, P. (2008). Ya-sam kak drugoi [I myself like the Other]. Moscow: Izdatel'stvo Gumanitarnoi literatury. (in Russian)

Shpet, G. (1996). Yavlenie i smysl: fenomenologiya kak osnovnaya nauka i ee problemy [The phenomenon and meaning: phenomenology as the main science and its problems]. Tomsk: Vodolei. (in Russian)

Starovoytenko, E. B. (2013). Dostizhenie sebya v otnoshenii k Drugomu [The achievement of Self in relation to the Other]. Mir Psikhologii, 74(2), 71-85. (in Russian)

Starovoytenko, E. B. (2015). Personologiya: zhizn' lichnostiv kul'ture [Personology: the life of the individual in culture]. Moscow: Akademicheskii proekt. (in Russian)

Starovoytenko, E. B. (2016). Genez Ya v otnoshenii k Drugomu [Genesis of the I in relation to the Other]. In M. I. Volovikova, A. L. Zhuravlev, \& N. E. Kharlamenkova (Eds.), Psikhologicheskie issledovaniya lichnosti: istoriya, sovremennoe sostoyanie, perspektivy [Psychological studies of personality: history, current state, perspectives] (pp. 117-135). Moscow: Institute of Psychology of RAS. (in Russian)

Starovoytenko, E. B. (2017). Productivity of the dialogical relationships Self - Other. Psychology. Journal of the Higher School of Economics, 14(3), 408-432. (in Russian) 
Starovoytenko, E. B. (2018, a). Ya-neizvestnoe v otnosheniyakh lichnosti k sebe i Drugomu [The Unknown I in the relationship of the individual to themselves and to the Other]. Mir Psikhologii, 3, 35-49. (in Russian).

Starovoytenko, E. B. (2018, b). A non-dialogic relation to the Other: Regression or opposition to dialogicity. Psychology. Journal of the Higher School of Economics, 15(4), 728-746.

Turovskii, M. B. (1997). Fenomenologicheskaya kontseptsiya kul'tury. Filosofskie osnovaniya kul'turologii [The phenomenological concept of culture. Philosophical foundations of cultural studies]. Moscow: ROSSPEN. (in Russian)

Zaretskii, Yu. P. (2007). Samoidentifikatsiya ili "modelirovanie Ya". Postklassicheskii kontsept sub" ektivnosti v istoriografii [Self-identification or "modeling of the I". A postclassical concept of subjectivity in historiography]. In A. A. Savanidze \& P. Yu. Uvarov (Eds.), Sotsial'naya identichnost' srednevekovogo cheloveka [Social identity of a medieval person] (pp. 9-21). Moscow: Nauka. (in Russian)

Elena B. Starovoytenko - professor, head of the Centre for Fundamental and Consulting Personology, School of Psychology, Faculty of Social Sciences, National Research University Higher School of Economics, D.Sc.

Research area: methodology of psychology, theoretical psychology of personality, personology, psychology of life relationships of personality, cultural personality psychology, psychology of cognition, psychology of reflection.

E-mail: helestaOS@yandex.ru 